\title{
Study on the Air Dispersion Characteristics along the West Coast of Korean Peninsula
}

\author{
Rajib Pokhrel $^{1 *}$, Inhyeong Cho ${ }^{1}$, Ram K. Sharma ${ }^{2}$, Heekwan Lee ${ }^{1}$ \\ ${ }^{1}$ School of Urban and Environmental Engineering, University of Incheon \\ 12-1 Songdo-Dong, Yeonsu-Gu, Incheon, South Korea \\ ${ }^{2}$ Pulchowk Campus, Institute of Engineering, Tribhuvan University, Pulchowk, Lalitpur, Nepal
}

\begin{abstract}
When the temperature difference between land and sea surface along coastline is large enough, thermally induced circulation is likely developed in the coastal region, called as Sea/Land $(\mathrm{S} / \mathrm{L})$ breeze. It has been an important issue in coastal region because of its significant role for the transport, dispersion of air pollutants generated in coastal regions. Meso-scale modeling was carried out using the commercial modeling tool 'A2C flow / A2C t\&d (A2C represents the Atmospheric to Computational fluid dynamics and t\&d represents the transport and diffusion)' to characterize the meso-scale circulation of pure breeze in the study region $(125.22 \mathrm{E}, 36.32 \mathrm{~N}$ to $127.95 \mathrm{E}, 38.39 \mathrm{~N})$ in late July for typical summer conditions of Korea. Maximum potential temperature differences were approximately $5 \mathrm{~K}$ and $14 \mathrm{~K}$ in early morning and mid day, respectively in the study domain. Strong land breeze was observed around 6AM and it was neutralized to transition stage between 9AM $10 \mathrm{AM}$ then the sea breeze started. Maximum speed of sea breeze, approximately $2.5 \mathrm{~m} / \mathrm{s}$ was found around 3PM which is about double of land breeze $(1.5 \mathrm{~m} / \mathrm{s})$. With the declination of sun energy with the passing of time, sea breeze lost its momentum and reached to transition stage between (9PM $10 \mathrm{PM})$. The penetration lengths of sea breeze and land breeze are approximately $25 \mathrm{~km} \sim 30 \mathrm{~km}$ and $20 \mathrm{~km} \sim 25 \mathrm{~km}$, respectively while the suction lengths of sea breeze and land breeze are approximately $15 \mathrm{~km} \sim 20 \mathrm{~km}$ each. In addition, the maximum depths of the S/L breeze are approximately $400 \mathrm{~m}$ and $1200 \mathrm{~m}$, respectively in early morning and sometimes in mid day along the coastal area.
\end{abstract}

Keywords: Coastal meteorology, S/L breeze circulation, air dispersion, penetration length, mixing height

\section{Introduction}

The coastline marks the boundary between sea and land temperature. When the differential heating of land and sea surface is significant, a temperature discontinuity is developed on both sides of the coastline, and when the temperature difference between the land and sea surface is large enough and ambient flow is weak, thermally induced micro-scale turbulences to mesoscale circulations are likely to develop at both sides of the surface temperature discontinuity (Hsu, 1988; Rani et al., 2010). S/L breeze circulation is one of the best examples of such mesoscale circulation system (Fredrick and Edward, 1979). Atkinson (1971), Sweet (1981), Hsu (1988) and Arya (1999), among others, have explained how the S/L breeze develops due to the diurnal heating/cooling of the land adjacent to the ocean.

The dynamic air flow ( $\mathrm{S} / \mathrm{L}$ breeze) which is generated by the difference in temperature and pressure gradients between landward and seaward play vital role for the control of temperature in the coastal area (Hsu, 1988). It is also well established that the $\mathrm{S} / \mathrm{L}$ breeze circulation associated with Thermal Internal Boundary Layer (TIBL) and it is mainly through the turbulence process 
(Srinivas et al., 2007). Different aspects and mechanism of S/L breeze are studied for several years in different coastal regions in the world (Biggs et al., 1962; Melas et al., 1995; Chiba, 1997; Chiba et al., 1999; Liu et al., 2002; Bastin et al., 2005; Fan et al., 2008). Bastin et al. (2005) reported that the depth of the breeze flow was less than $200 \mathrm{~m}$ during the night and reached thousand of meter during the day. Fan et al., (2008) observed that the average height of atmospheric boundary layer during the night was $200 \mathrm{~m}$, while the maximal value during day time was $1200 \mathrm{~m}$. Similar results were reported by Lee et al. (2004) and Rani et al. (2010).

The development of TIBL associated with onshore and offshore flows have greater significant for the dispersion of air pollution around the coastal region. Mostly, air pollutants generated near the coastal line transported to the landward during the day time along with the sea breeze and seaward during the night time along with the land breeze (Hsu, 1988). Fan et al. (2008), Kim et al. (2007), Karim et al. (2007), etc. reported that the wind flows over the hilly or mountain terrain transport air pollutants to higher altitude and lower level at the plain area but the horizontal penetration length at the plain area is longer than the mountainous area. Sea breeze penetrated to $15 \mathrm{~km}$ at Beaufort Sea coast, Alaska, United States (Kozo, 1982) but the sea breeze penetrated far inland area approximately $200 \mathrm{~km}$ in Australia (Simpson, 1994). In this study, researcher has focused to estimate the TIBL of S/L breeze in the west coast of Korean Peninsula using a commercial air modeling tool.

\section{S/L Breeze Modeling}

Incheon Metropolitan city located at the west coast $\left(37^{\circ} 29^{\prime} \mathrm{N}, 126^{\circ} 38^{\prime} \mathrm{E}\right)$ of Korean Peninsula, has been rapidly growing compared to other area. The territory covers small to big islands situated near to the Incheon coastal area as in Fig. 1. It is recognized as the third biggest city of Korea. Reclamation of sea shore, construction of high rise building for increased population, coverage of open land by cement concrete or asphalt, etc., are major changes in Incheon area. In addition, major energy sources power plants, airport and port, etc., have been in operation along the coastal line and nearby islands which subsequently affect the local atmospheric environment (Jung et al., 2009). Complex geography, multiple land use pattern, etc. generate complex wind flow around the Incheon coastal area.

Lee et al. (2004) and Jeong et al. (2008) calculated the Sea Breeze Index (SBI - it is the indicator to judge whether the wind is sea breeze or not) as suggested by Biggs (1962) when the sea breeze was observed about 200days in 2000. It indicates that Incheon area frequently experiences circulation of wind from land to sea, i.e. land breeze, and vice-versa, i.e. sea breeze. This cyclic behavior of the S/L breeze play an important role for the air pollutants transport and diffusion in coastal region but this coastal recirculation refers to the return of air masses to their source region after a period of time due to the change from land to sea breeze (Hsu, 1988; Miller et al., 2003). Hence, therefore it is essential to estimate the boundary of $\mathrm{S} / \mathrm{L}$ breeze before studying the impact of air pollutants from the sources to the surrounding area. There are numbers of methods available and adopted to estimate the boundary layer of S/L breeze such as field monitoring (using radio sonde, lidar, weather station, etc.), analytical model, and numerical simulation (computer model). 


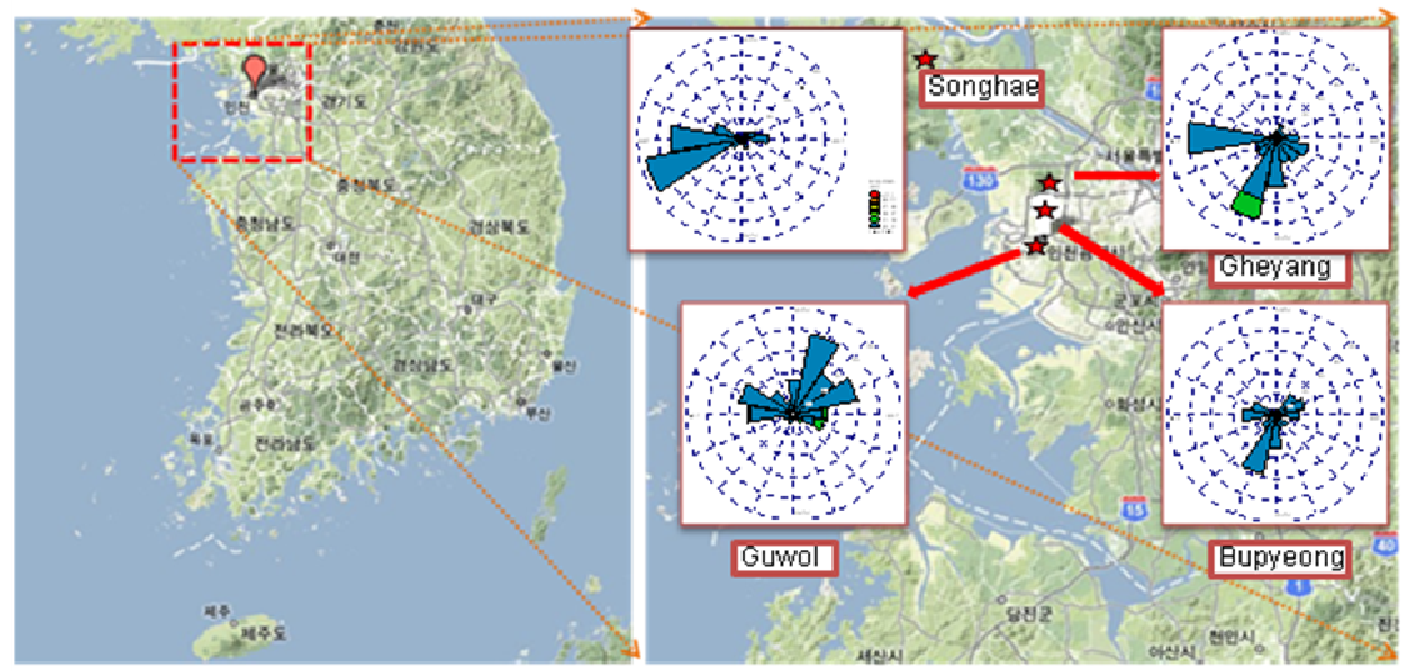

Fig. 1: Study site (a) South Korean Peninsula, and (b) magnifying view of study domain

Atmospheric systems are divided into various groups such as micro scale, meso-scale, regional scale etc. For particular study cases including sea land breeze, vegetation and snow breeze, mountain valley wind, etc. are classified into meso-scale atmospheric systems (Pielke et al., 1994). Meso-scale atmospheric systems are sub-divided into two groups: (1) those forced primarily by surface inhomogeneties (terrain and physiographic - induced mesoscale systems), and (2) those forced primarily by instabilities in travelling large - scale disturbances, synoptically induced mesoscale systems. First group includes sea and land breezes, mountain valley wind, urban circulations, and forced air flow over rough terrain; the second group includes squall lines, hurricanes, and travelling mesoscale cloud clusters (Pielke et al., 1994).

Since early 1970s, computer capability has improved sufficiently to permit three-dimensional simulations. McPherson (1970) was the first to report for such calculations of the sea breeze and was followed, for instance, by the studies of Pielke (1994), Yamada et al. (1988, 1989 and 1999) and Kim et al. (2007) to present scientists. Recently numerous techniques for complex mesoscale modeling have developed and practiced for atmospheric modeling (Fast et al., 1995; Pace, 2000). Astitha et al. (2008) used SKIRON/Eta atmospheric and dust-modeling system, RAMS atmospheric modeling system, and air quality model CAMx. Schutze et al. (2008) used computational fluid dynamics (CFD) code FLUENT 6 together with the particle model (FPM). Lin et al. (2008) used MM5 mesoscale model in order to study and evaluate the impact of the heat island effect on regional weather over Taiwan. Srinivas et al. (2007) also used it to simulate $\mathrm{S} / \mathrm{L}$ breeze circulation on the south east coast in the Chennai region of India. Although those models have wide range of applications, they have certain limitation of data accuracy (Evans, 2002; Srinivas, 2007). Mizak et al. (2007) used NOAA Buoy model to estimate the air-sea transfer rates of highly soluble gases over coastal water bodies. Rani et al. (2010) applied high resolution model (HRM) to estimate the internal boundary layer of S/L breeze in south west coast of Indian sub-continent (Thumba) where she used the data grid resolution of $28 \mathrm{~km}$. In this study, authors focus to understand $\mathrm{S} / \mathrm{L}$ breeze interaction in west coast of Korean peninsula by introducing three dimensional mesoscale model 'Atmospheric to Computational Fluid Dynamics (A2C flow / A2C t\&d)' where the t\&d stands for transport and diffusion.. 


\section{Modeling Method}

We focused pure breeze case and applied a commercial software $\mathrm{A} 2 \mathrm{C}$ flow / $\mathrm{A} 2 \mathrm{C}$ t\&d, an updated version of HOTMAC / RAPTAD for simulation where the CFD (Computational Fluid Dynamics) capabilities are added to HOTMAC and RAPTAD. It is a three dimensional computer code that forecasts wind, temperature, humidity, clouds, fog, and atmospheric turbulence distributions over complex surface conditions. The basic equations of HOTMAC are described in detail by Yamada et al. $(1988,1989)$. The deviation mean value is solved instead of the absolute value of potential temperature. The magnitude of the potential temperature is about $300 \mathrm{~K}$, but the deviations from the large-scale values are on the order of 10K or less (Yamada, 2000). RAPTAD is based on the Lagrangian theory in which number of puffs are released from the source and the characteristics of puffs change with the time of puffs release from the sources where the location of the center, the size and age of the puff, are computed at every time step.

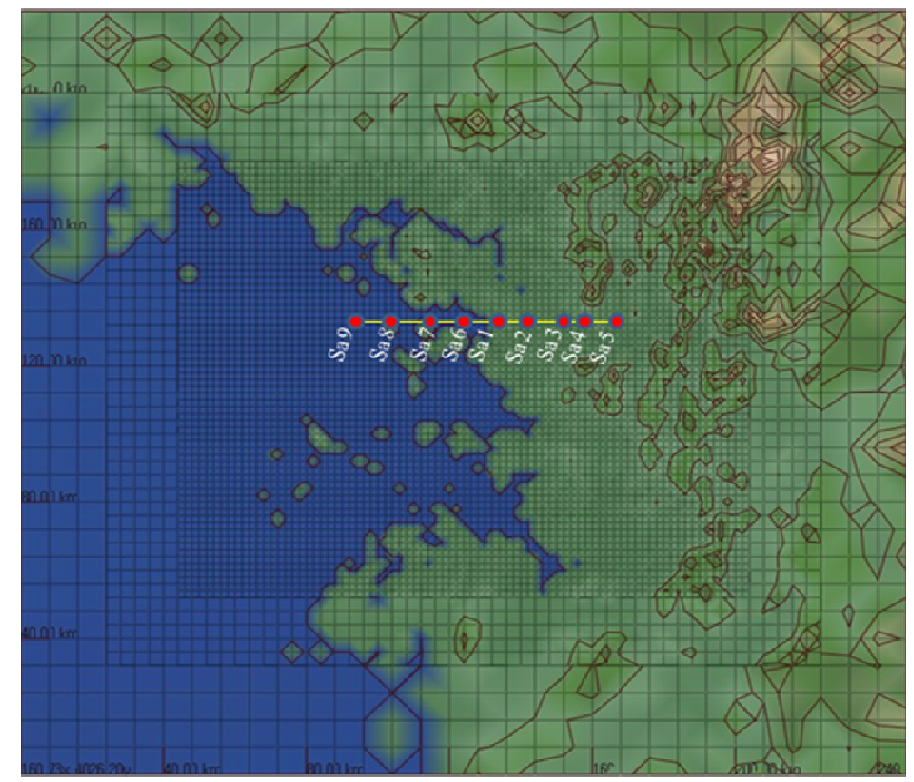

Fig. 2: Study domain located at the west coast of Korean Peninsula, Sa1 Sa15 represent the sampling point set for wind and temperature data.

USGS 30" resolution geographic data (approximately $800 \mathrm{~m}$ resolution at mid latitude) was used for extracting the geographic information to set the modeling domain. The modeling domain lies between $125.22 \mathrm{E} 36.32 \mathrm{~N}$ to $127.95 \mathrm{E} 38.39 \mathrm{~N}$ which covers Incheon, Seoul and its nearby mountains and sea area as in Fig. 1(b). The modeling period was selected in late July (Julian day 198 204) when the occurrence of S/L breeze was maximum (Lee et al., 2004; Jeong et al., 2008). Although, we simulated for Julian day 198 204, the results are summarized for Julian day 200, middle of modeling period, to avoid the effects of initial conditions. The average potential temperature $297 \mathrm{~K}$ and reference pressure, $1007 \mathrm{hPa}$ were set by referring the published data (Annual Climatological Report, 2008). The inversion height is approximately the boundary layer height during the day time in usual cases. The inversion height, $1000 \mathrm{~m}$ was set as initial condition based on the references (Lee, et al., 2004; Jeong, et al., 2008). Initial wind speed, $0 \mathrm{~m} / \mathrm{s}$ was set by assuming the pure $\mathrm{S} / \mathrm{L}$ breeze case i.e. no influence of external or synoptic wind. 
There was no wind flow at the beginning of modeling period therefore the initial wind direction is insignificant. In addition, the nudging option set active for maintaining boundary conditions same as the initial values. Earth rotation option set active by considering the Coriolis effect. Rests of the parameters such as turbulence variables, radiation variables, etc. were set as the default values.

The modeling domain has divided to three nested domains with grid resolution of $2 \mathrm{~km}, 4 \mathrm{~km}$ and $8 \mathrm{~km}$, respectively as shown in Fig. 2. The resolution of nested grid increased to double from outer to inner domain. Sampling sites Sa1 Sa9 were set in the domain as in Fig. 2 up to approximately $35 \mathrm{~km}$ form coastline to inland and offshore. The distance of the sampling points from the nearest coastal line and the geographical elevation are summarized in Table 1. Further simulation was carried out and the simulation data were stored in the database management system. The boundary layer or the most effective zone of S/L breeze was analyzed based on the wind flow vector and wind speed at different parts in the study domain.

Table 1: Geographical location and surface elevation of sampling sites in this study domain

\begin{tabular}{|l|c|l|}
\hline Sites & $\begin{array}{l}\text { Surface } \\
\text { Elevation }(\mathrm{m})\end{array}$ & Approximate distance from the coastline \\
\hline Sa1 & 46 & $3 \mathrm{~km}$ (Near to coast line) \\
\hline $\mathrm{Sa} 2$ & 9 & $10 \mathrm{~km}$ (Inland) \\
\hline $\mathrm{Sa} 3$ & 32 & $20 \mathrm{~km}$ (Han river is located very near to the sampling site, Inland) \\
\hline $\mathrm{Sa} 4$ & 39 & $25 \mathrm{~km}$ (Inland) \\
\hline $\mathrm{Sa} 5$ & 19 & $35 \mathrm{~km}$ (Inland) \\
\hline $\mathrm{Sa} 6$ & 0 & $5 \mathrm{~km}$ (Offshore) \\
\hline $\mathrm{Sa} 7$ & 5 & $15 \mathrm{~km}$ (Offshore, at the small island) \\
\hline $\mathrm{Sa} 8$ & 10 & $25 \mathrm{~km}$ (Offshore, at the small island) \\
\hline Sa9 & 0 & $35 \mathrm{~km}$ (Offshore) \\
\hline
\end{tabular}

\section{Results and Discussion}

Fig. 3 (a), (b), (c), and (d) demonstrate the horizontal wind vectors above $10 \mathrm{~m}$ from the surface level at 6AM, 9AM, 3PM, and 10PM. The temperature of the earth surface varied with the variation of sun energy. Even the sun energy is constant; the temperature differs significantly place to place due to the different land use pattern and different specific heat capacities of land use objects. After the sunset, the land surface releases heat faster than water body, subsequently the land surface temperature becomes lower than the sea surface in late evening to early morning before sunrise (Miller et al., 1983; Hsu, 1988). Consequently, the pressure above sea surface becomes lower than pressure above land surface which caused the dynamic air flow from land to seaward (land breeze) and it gained its maximum speed just before sunrise around 6AM as in Fig. 3(a). After the sunrise, the land surface heats faster than water surface because of the lower specific heat capacity of land than the sea water. Correspondingly, the potential temperature difference between land and the sea surface reaches to minimum which results the collapse of 
land breeze and reaches to transition stage as in Fig. 3(b) around 9AM. When the temperature of the land surface reaches considerably more than sea water, air rises up and pressure above land surface become lower than the pressure above sea water surface. Then air flows from higher pressure side to lower pressure, i.e. sea breeze as in Fig. 3(c).The land surface temperature diminishes faster than water surface temperature with the declination of sun energy and hence reaches to the transition period again around 10PM as in Fig. 3(d).
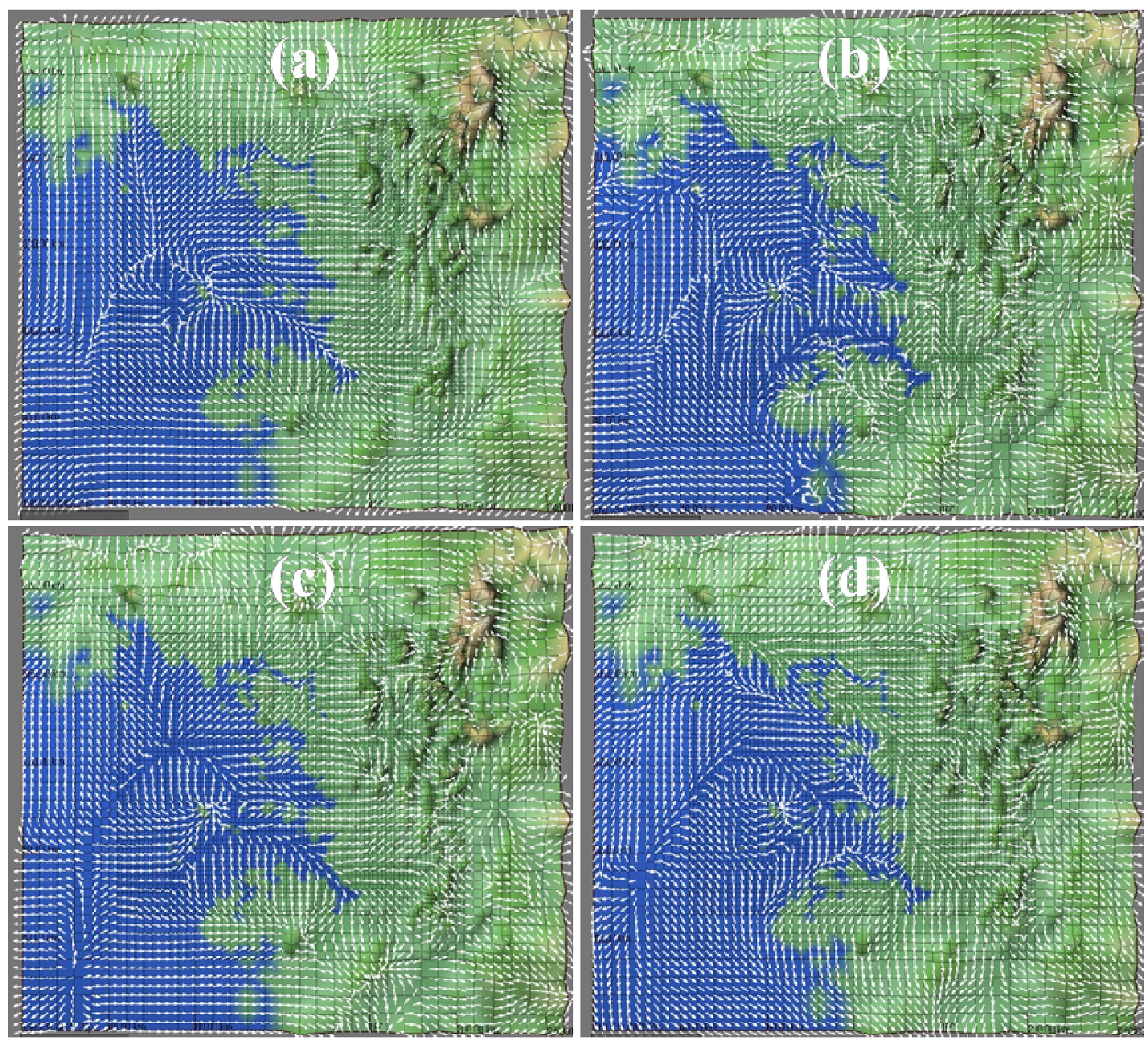

Fig. 3: Horizontal wind vector above $10 \mathrm{~m}$ from the surface level at (a) 6AM, (b) 9AM, (c) 3PM, and (d) 10PM.

Fig. 4 displays the diurnal variation $\mathrm{S} / \mathrm{L}$ breeze above $10 \mathrm{~m}$ from the ground surface at different sampling points as shown in Fig. 2 and Table 1. Sampling site Sa1 is located at the coast line where distinct cyclic S/L breeze mechanism identified as in Fig. 4. The negative wind speed represents the land breeze and positive wind speed represents the sea breeze in the Fig. 4. The land breeze starts after 10PM at coastline and the maximum land breeze is seen around 6AM. It becomes calm around 9AM 10AM and then sea breeze forms. Sea breeze accelerates continuously and gains the maximum velocity around 3PM and again decelerates to calm stage 
around 9PM 10PM. It also shows that the maximum speed of sea breeze $(2.5 \mathrm{~m} / \mathrm{s})$ is approximately double than the maximum speed of land breeze $(1.5 \mathrm{~m} / \mathrm{s})$ at Incheon coastline. As the distance increases from the coastline, the breeze continuously loses its energy which can be identified from the wind speed value at different sampling sites in Fig. 4. There is calm wind speed of $0.5 \mathrm{~m} / \mathrm{s}$ or less at sampling site $\mathrm{Sa} 5$.

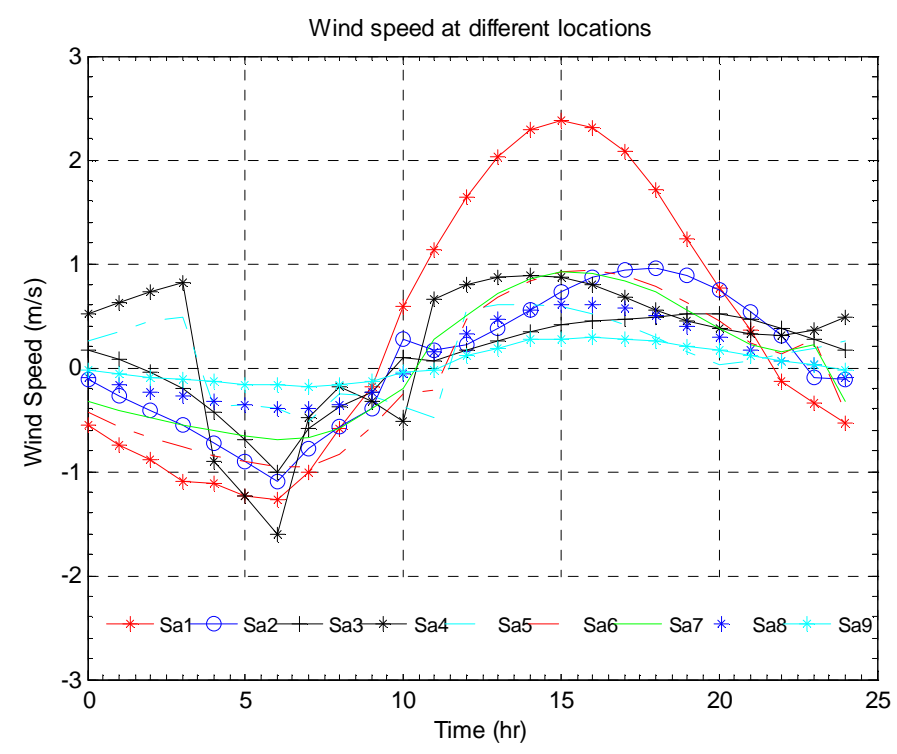

Fig. 4: Diurnal variation of wind speed above $10 \mathrm{~m}$ form the surface at the different sampling sites where negative wind represents land breeze and positive wind speed represents sea breeze.

Sites Sa 3 and $\mathrm{Sa} 4$ are approximately $20 \mathrm{~km}$ and $25 \mathrm{~km}$ from the coastline where breeze nearly reaches to calm and it is affected by local wind generated by nearby mountain and Han River. Site Sa5 is approximately $35 \mathrm{~km}$ from the coastal line where wind speed is less than $0.5 \mathrm{~m} / \mathrm{s}$ ie calm condition. Based on the wind flow characteristics in Fig. 4, it is understood that the breeze mechanism vary place to place. The sea breeze penetrates to inland area approximately $25 \mathrm{~km} \sim 30 \mathrm{~km}$ while the land breeze penetrates to offshore area approximately $20 \mathrm{~km} \sim 25 \mathrm{~km}$. The suction length of sea breeze and land breeze are approximately $15 \mathrm{~km} 20 \mathrm{~km}$ in Incheon. However, maximum penetration length $(200 \mathrm{~km})$ of sea breeze was reported in Australia (Simpson, 1994) and penetration length (15km) in Beaufort sea coast, Alaska (Kozo, 1982). 

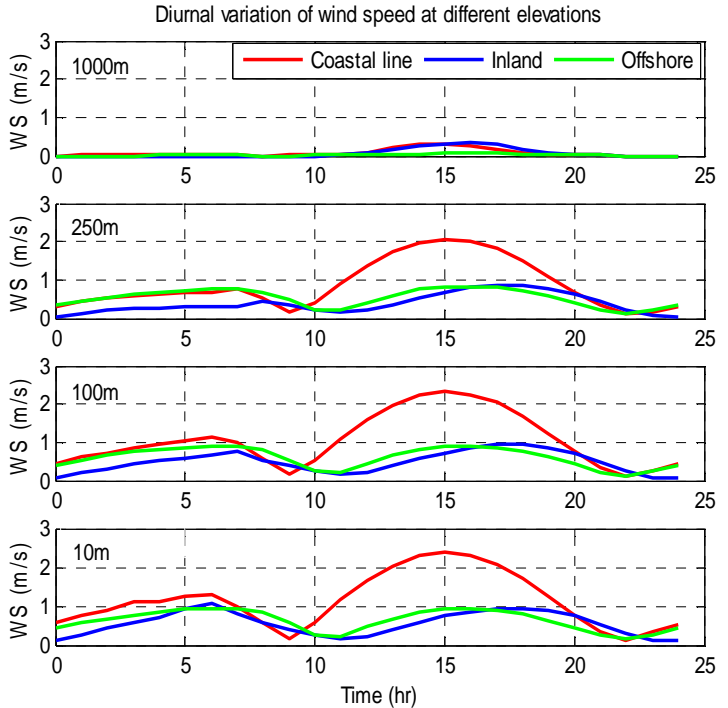

(a)

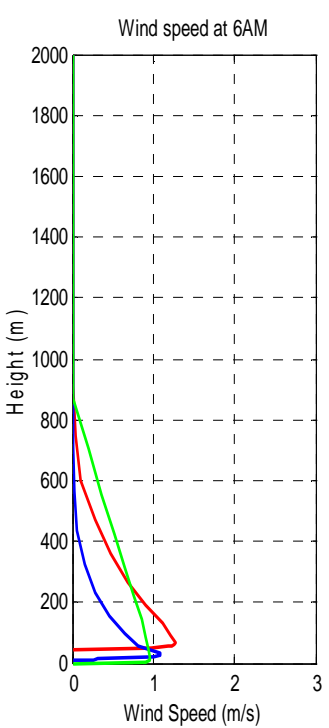

(b)

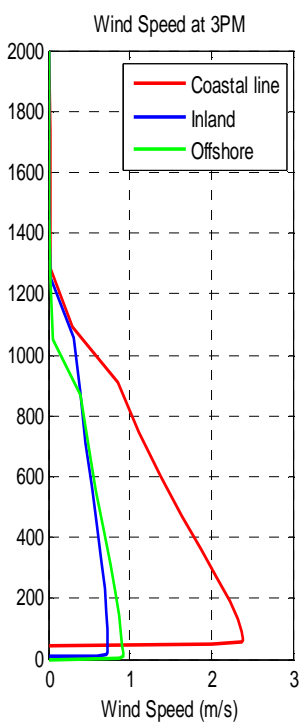

(c)

Fig. 5: (a) Diurnal variation of wind speed at 10m, 100m, 250m and 1000m elevations, (b) vertical wind profile at 6AM and (c) vertical wind profile at 3PM in coastline, inland and offshore regions. WS represents the wind speed.

Fig. 5(a) shows the diurnal variation of S/L breeze components at three locations (offshore, coast line, and inland points) for Julian day 200 and they are separated approximately $8 \mathrm{~km}$ apart from each other. Four different panels indicate the simulation for different vertical levels, $10 \mathrm{~m}, 100 \mathrm{~m}$, $250 \mathrm{~m}$, and $1000 \mathrm{~m}$, respectively from the corresponding ground surface. There are two summits in each graph in Fig. 5(a). Left hand curve in Fig. 5(a) represents the land breeze (around 10PM 9AM) and right hand curve in Fig. 5(a) represents the sea breeze (around 10AM 9PM). There is noticeable S/L breeze cycle in lower altitude but the land breeze nearly collapses at an altitude of $250 \mathrm{~m}$, especially at inland point but the sea breeze is significant until few hundreds meter higher altitude. Sea breeze collapses approximately $1000 \mathrm{~m}$ altitude mostly at offshore line. Fig. 5(b) and (c) demonstrate the vertical wind profile at 6AM (maximum land breeze at coast line) and 3PM (maximum sea breeze at coast line), respectively. It is concluded that the maximum depth of land breeze at inland area, coast line, and offshore area are approximately $400 \mathrm{~m}, 600 \mathrm{~m}$, and $800 \mathrm{~m}$, respectively. On the other hand, the maximum depth of sea breeze in inland area, coast line and offshore are approximately $1200 \mathrm{~m}, 1200 \mathrm{~m}$, and 1000m, respectively. According to the results published by Bastin (2005), the depth of breeze flow is less than $200 \mathrm{~m}$ during the night and it reached $1000 \mathrm{~m}$ during the day. Similar results were reported by Lee et al. (2004), Fan et al. (2008), and Rani et al. (2010).

\section{Conclusion}

$\mathrm{S} / \mathrm{L}$ breeze has been an important issue in coastal region because of its significant role for the transport, diffusion and dilution of air pollutants generated in coastal area. A commercial mesoscale modeling tool was successfully applied to understand the meso-scale circulation of pure 
breeze by using geographical data resolution of 30" where modeling domain of size $248 \mathrm{~km} \times 224 \mathrm{~km}(125.22 \mathrm{E}, 36.32 \mathrm{~N}$ to $127.95 \mathrm{E}, 38.39 \mathrm{~N})$ was set by covering both sea and land area.

Maximum potential temperature difference during land breeze and sea breeze were observed at early morning and at the mid day around 2PM at the coastline of the modeling domain which was significant for the generation of S/L breeze. Strong land breeze was observed around 6AM just before sunrise while maximum speed of sea breeze approximately $2.5 \mathrm{~m} / \mathrm{s}$ was identified around $3 \mathrm{PM}$ which was about double of land breeze $(1.5 \mathrm{~m} / \mathrm{s})$. The penetration length of sea breeze and land breeze were $25 \mathrm{~km} \sim 30 \mathrm{~km}$ and $20 \mathrm{~km} \sim 25 \mathrm{~km}$, respectively while suction length of sea breeze and land breeze were $15 \mathrm{~km} \sim 20 \mathrm{~km}$ each. In addition, the maximum depth of the sea breeze and land breeze at the coast line were approximately $1200 \mathrm{~m}$ and $400 \mathrm{~m}$, respectively. Hence the vertical height of the breeze circulation for the day time was approximately triple than the breeze circulation for night and early morning.

\section{REFERENCES}

[1] Annual climatological report, Korean meterological administration, 2008. South Korea.

[2] Astitha M., Kallos G., Katsafados P., Air pollution modeling in the Mediterranean region: analysis and forecasting of episodes. Atmos. Res. 89, 358-364, 2008.

[3] Atkinson G.D., Forecasters guide to tropical meteorology, Air Weather Service, US Air Force, 1971.

[4] Bastin S., Drobinski P., Dabas A., Delville P., Reitebuch O., Werner C., Impact of the Rhone and Durance Valleys on sea-breeze circulation in the Marseille area. Atmos. Res. 74, 303-328, 2005.

[5] Biggs W.G., Graves M. E., A Lake Breeze Index. J. Appl. Meteorol., 1, 474-480, 1962.

[6] Chiba O., Kobayashi F., Naito G., Sassa K., Helicopter observations of the sea breeze over a coastal area. J. Appl. Meteorol., 38, 481-492, 1999.

[7] Evans W. R., Quantification of the effects of data denial and limitation in MM5 initialization on forecast accuracy, Thesis, AFIT/GM/ENP/02M-03, 2002.

[8] Fan S., Wang B., Tesche M., Engelmann R., Althausen A., Liu J., Zhu W., Fan Q., Li M., Ta N., Song L., Leong, K., Meteorological condition and structures of atmospheric boundary layer in October 2004 over Pearl River Delta area, Atmos. Environ., 42, 61476186, 2008.

[9] Fast J. D., O'Steen B. L., Addis R. P., Advanced atmospheric modeling for emergency response. J. Appl. Meteorol., 34, 3, 626-649, 1995.

[10] Fredrick K. L., Edward J. T., The Atmosphere - An Introduction to Meteorology. Prentice Hall, 1979. 
[11] Hsu S. A., Coastal Meteorology. Academic press, Inc. (London) LTD., pp. 141-179, 1988.

[12] Jeong J., Lee I. H., Lee H., Estimation of the effective region of Sea/Land breeze in west coast using numerical modeling. J. KOSAE 24, 2, 259-270, 2008..

[13] Jung C. H, Pokhrel R., Lee H. K., The impact of power plants on the environment and region - Focus on Incheon area according to the $3^{\text {rd }}$ electric support action plan. J. E.I.A. Korea 18, 4, 195-208, 2009.

[14] Karim B., Mansour B. F., Elouragini S., Impact of a sea breeze event on air pollution at the Eastern Tunisian Coast. Atmos. Res., 86, 162-172, 2007..

[15] Kim D., William R. S., An online coupled meteorological and air quality modeling study of the effect of complex terrain on the regional transport and transformation of air pollutants over the Western United States, Atmos. Environ., 41, 2319-2334, 2007.

[16] Kozo T. L., An observational study of sea breezes along the Alaskan Beaufort sea coast: Part I. J. Appl. Meteorol., 21, 891-905, 1982.

[17] Lee I., Lee H., Analysis of meteorological characteristics of Sea/Land breeze in western coastal region. J. Korean Society of Urban Environ., 4, 1, 63-71, 2004.

[18] Lin C.Y., Chen W. C., Liu S. C., Liou Y. A., Liu G. R., Lin T. H., Numerical study of the impact of urbanization on the precipitation over Taiwan. Atmos. Environ., 42, 29342947, 2008.

[19] Liu H., Chan J. C. L., An investigation of air-pollution pattern under sea-land breezes during a severe air-pollution episode in Hong Kong. Atmos. Environ., 36, 591-601, 2002.

[20] Melas D., Ziomas I. C., Zerefos C. S., Boundary layer dynamics in an urban coastal environment under sea breeze conditions. Atmos. Environ., 29, 24, 3605-3617, 1995.

[21] Miller S. T. K., Keim B. D., Talbot R. W., Mao H., Sea breeze: Structure, forecasting, and impacts. Rev. Geophys., 41, doi: 10.1029/2003RG000124, 2003.

[22] Peilke R. A., Pearce R. P., Mesoscale modeling of the atmosphere. 25, Publisher: American Meteorological Society, Boston, MA, 1994.

[23] Pokhrel R., Lee H., Estimation of the effective zone of sea/land breeze in a coastal area, A. P. R., 2, 106-115, 2011.

[24] Rani S. I., Ramachandran R., Subrahamanyam D. B., Characterization of sea/land breeze circulation along the west coast of Indian sub-continent during pre-monsoon season., Atmos. Res., 95, 367-378, 2010.

[25] Schutze M., Stratmann F., Numerical simulation of cloud droplet formation in a tank, Comput. Geosci., 34, 1034-1043, 2008.

[26] Simpson J. E., Sea Breeze and Local Wind. Cambridge University Press, New York, 234 pp, 1994. 
[27] Srinivas C.V., Venkatesan R., Singh A. B., Sensitivity of mesoscale simulations of landsea breeze to boundary layer turbulence parameterization, Atmos. Environ., 41, 2534$2548,2007$.

[28] Sweet W., Fett R., Kerling J., LaViolette P., Air-sea interaction effects in the lower troposphere across the north wall of the Gulf Stream. Mon. Wea. Rev., 109, 1042-1052, 1981.

[29] Yamada T., A numerical simulation of urbanization on the local climate, J. Wind Eng. Ind. Aerodyn., 81, 1-19, 1999.

[30] Yamada T., Numerical simulation of airflows and tracer transport in the south western United States, J. Appl. Meteorol., 39, 399-411, 2000.

[31] Yamada T., Bunker S., Development of Nested Grid, Second Momentum Turbulence Closure Model and Application to the 1982 ASCOT Brush Creek Data Simulation, J. Appl. Meteorol., 27, 562-578, 1988.

[32] Yamada T., Kao J. C. Y., Bunker S., Air flow and air quality simulation over the western mountain region with the four dimensional data assimilation technique, Atmos. Environ., 23, 3, 539-554, 1989. 